\title{
Indian Government's Sustainable Initiatives and the Millennials Behavior
}

\author{
Saba Jafri ${ }^{1}$ \\ ${ }^{1}$ Amity University, Haryana, India \\ Correspondence: Saba Jafri, Amity University, Haryana, India. E-mail: sabajafri2002@gmail.com
}

Received: December 4, 2019

Accepted: January 10, 2020

Online Published: January 30, 2020

doi:10.5539/jsd.v13n1p78

URL: https://doi.org/10.5539/jsd.v13n1p78

\begin{abstract}
This conceptual article examines how Sustainable Initiatives of government and corporates can help shape behaviours of Millenials that can address the different needs and expectations of potential and existing employees. This can result in a sustained competitive advantage for the firms and enhanced self-esteem for the existing and prospective employees. Sustainability efforts should encourage youngsters to imbibe behaviours that are in line with governments and corporates' efforts to create a better planet to live in. These behaviours should help firms attract and retain a high-quality workforce because by integrating Sustainable HRM practices into the employee value proposition, they can establish a unique, employer brand. The paper also highlights the challenges faced by the government and corporates together to achieve these sustainable objectives.
\end{abstract}

Keywords: sustainability, sustainable development, sharing economy, millenials, green bonds

\section{Introduction}

Governments all over the world play a pivotal role in driving sustainability initiatives. This helps markets function efficiently and drive progress towards sustainability development goals. India is one of the fastest-growing economies with a growth rate of 6 percent in 2018-2019,(UN Trade agency) and the second-largest population resulting in enhanced industrialization and hence, environmental degradation. Also, India is one of the most polluted countries in the world, with twenty-two out of the 30 worst polluted cities in the world (Greenpeace, The Guardian, International edition, 2019).

More and more countries across the globe are beginning to realize serious environmental threats due to human activities(McMichael.A,2008;Sherbinin,2007; D.Briggs,2003)and have started working towards reducing the harmful impact of their business activities on the environment. This realization and concern of businesses towards the environment and society have led to the emergence of a concept called 'sustainable development'(Pisani.D,2006, Waas.T, 2011). It emphasizes the need to promote sustainability and advocates that form of development which minimizes the negative impact on the environment and society. The focus of this research paper is to highlight how businesses, government(Narain.J,2012) and consumers are coping with this challenge of increased environmental risks. To extend these studies we examine how specifically government initiatives, lead to sustainable behaviours of Millennials in India?

In a study (Abbas, Aman, 2019) it is shown how social media impacts behaviour of university students to sustainable education.

According to Deloitte database, 2016, India is having largest millennial population of 34 percent globally. According to, Pew research of 2014, Millennials fell within the age range of 18-33 years. According to Fuller(2013), marketers have forecasted that the Millennial market has a spending power worth $\$ 200$ billion. They have a high expenditure rate (O’Donnell2006) and even influence family purchase decisions(Morton 2002), thereby having an impact on the economy directly and indirectly. In particular, the personality and financial characteristics of Millenials show that they are a growing and powerful market segment.

Incorporating sustainability initiatives not only lessens negative environmental impacts but also enhances atmosphere and well-being of citizens of a nation. This has led to the development of latest societal trend of 'going green' by incorporating various sustainability initiatives.

Green behaviours are a joint responsibility of individual citizens, public authorities and industry (Sonigo et al.,2012). 
Researchers argue that the most serious environmental problems of over-population, global warming (Baus.D,2017), toxic waste and effluents (Thompson.R,2009), and overuse of agricultural and oceanic habitats(Kleemann.S,2019), are not just the issues restricted to science, but also of individual behaviour. Sustainable development also encourages the eco-innovation and green habits of employees (Yang.Y, 2019, Buhl.A,2016).

\section{Government Initiatives}

Definitions of sustainability vary; in fact, almost each organization that engages in sustainable activities has either their own definition of sustainability or a specific mission statement. The US Green Building Council defines green buildings as ones

that have significantly reduced or eliminated negative impacts not only on the environment but also on the occupants of the building (Abbaszadeh, Zagreus, Lehrer \& Huizenga, 2006). A sustainable workplace can be described as one that takes on social responsibility, ethical responsibility, improving health and safety, and improving the natural environment (Danish Trade Union Movement's Centre for Competence Development, 2004).

The Indian government is doing what it takes to prove its eco-friendly responsibility by taking sustainability initiatives and increasing awareness about the same amongst the masses.

India is one of the countries to curb pollution and promote sustainability. One of the initiatives in this direction was hosting the world environment day on June 5.

In India among the sustainability initiatives by the government are to name a few "Swachh Bharat Mission", "New mass movement against plastic use", "Promotion of electric vehicles" and "Save and Educate the Girl child".

The government of India is putting up policies in place to promote sustainable development. To truly engage the Indian public, therefore, the Indian government has put up a sophisticated, multi- dimensional campaign involving education, regulation, fiscal incentives, and social norm reinforcement. They have launched multi-media communication campaigns, seeking to portray sustainable living in a favourable light. Millennials are more environmentally and socially aware (Dabija.D,2018) and would invest and exhibit loyalty in products of companies having a reputation of sustainability.

Jackson 2005, opines that policy is never neutral but shapes our thinking, as in targets to reduce greenhouse gas emissions, communicate the seriousness of the environmental issue and (Janicke, 2011, 2012) has shown that countries with low environmental targets don't reach them whereas those with higher achievable targets surpass them.

Four main policy tools have been identified by Sonigo et al, 2012 which can encourage sustainable behaviours.

- Regulatory includes mandatory tools that put a ban or limit

certain products or behaviour, and requirements, such as

mandatory labelling.

- Economic where market-based instruments that influence purchasing

decisions through taxes, incentives, subsidies, penalties or grants

for sustainable enterprises.

- Information like product labels and information on energy bills.

- Behavioural tools or nudges aimed at influencing consumer behaviour by leading individuals to make choices that are better for the environment.

In continuance, with the four tools identified above, the behavioural tool is the one having maximum impact on the behaviour of people. Thus, we see there has been a vigorous use of famous personalities in India advocating ecological behaviours to make people aware of their importance. Studies (Hoffman, J, M.Yasmeen, Natt.N, et al, 2017) suggest that celebrities are people whose actions and decisions are emulated by wide audiences.

In line with the above-mentioned policy initiatives, the Indian government is making efforts to enhance the awareness of people about our sustainable future. Many corporates are contributing their bits in maintaining ecological balance even as they pursue growth. Launch of green skill development program focuses on developing green skills in youth to preserve and conserve the environment to create a sustainable future. 


\section{Theoretical Framework}

Theory of planned behaviour has been used to support our recommendation of government sustainability initiatives having an impact on behaviours of Millennials.

The theory has been used widely to predict and explain wide range of behaviours and intention. It states that behavioural achievement depends on both the motivation and the ability. College educated, Millennial's motivated by preference for vibrant, healthier neighbourhoods and good public transportation are helping derive a new economic resurgence in many Indian cities. Compact cities with robust public transportation systems produce fewer pollutants and consume land relatively frugally (Bannister, Watson, and Wood 1997; Camagni, Gibelli, and Rigamonti 2002; Muñiz and Galindo 2005 cited in Schoolman et al, 2014). In Indian context, many studies have provided empirical evidence in support of positive association between attitude toward green products and green buying behaviours. Khare (2015) found positive relation between past green attitude and green buying behaviour in a study among consumers from metropolitan cities in India. Manaktola and Jauhari (2007) who reported that attitude toward green practices in the lodging industry influences consumer's choice to stay in hotels adopting green practices. Prakash and Pathak (2017) study reported positive association between attitude toward eco-friendly packing and intention to purchase products with such packaging.

Social norms also contribute to intention to perform an action. Yadav and Pathak (2017) found that Social Norms significantly affects the Purchase Intention toward green products in general. For millennials in India, communication with peers about green consumerism had the greatest impact on their green buying behaviour, followed by family communication. This finding falls in line with previous research; as individuals reach adolescence, the roles played by peers as socialization agents become more important than families (Singh et al., 2006, cited in Muralitharan's and Xue.F,2016).

(Bandura, Adams and Beyer, 1977) shows that people's behaviour is strongly influenced by their confidence in their ability to perform it (i.e., by perceived behavioural control). Indian Millennials have confidence in their skills and view brands through a holistic lens and places greater reliance on the ethos and the value system of the brand. Brands that clearly show the source of their materials or establish work done for a specific cause tend to strike a chord with current and prospective customers.

Millennials are also eager for business leaders to be proactive about making a positive impact in society — and to be responsive to employees' needs.

They want to be active participants in the social purpose of the companies they work for, and businesses that build a workplace culture around these ideals are rewarded with highly engaged, enthusiastic and invested employees(livemint,2019)

Deloitte report, 2019, states, that Millennials in India are very optimistic about their social and political outlook, significantly higher than their global counterparts. They aspire to make a positive impact in community and society at large.

Martin.J ,2015, argues that the Millennials believe in sharing economy which encompasses online peer-to-peer economic activities as diverse as rental (Airbnb), for-profit service provision (Uber), and gifting (Freecycle), not investing their money in buying cars, property etc. and there has been a growing conscientiousness in two areas particularly well-being and social good. OYO rooms on the lines of Airbnb, Ola following Uber, are a few examples from India.

There has been a (Kuchinka.D,2018) change in the attitude of the young workforce towards a sustainable lifestyle. People are becoming more socially responsible and conscious of environmental aspects.

(Sheahan, 2005), Millennials have been identified to be different from the wider population in terms of their high environmental consciousness, a stronger preference for "green" (Smith, 2010) and willingness to buy eco-friendly products (Rogers, 2013). (Morgan Stanley, 2017), Millennials are better educated, and better connected to information and the world.

(Chaudhary et al, 2018), posits Millennials in India are indulging in purchase intentions based on their environmental concern. Nielsen Q2, 2017, report shows India as top most countries where consumers demand corporate sustainability. This shows consumers' consciousness for sustainability issues is growing.

\section{Corporates Contribution to Sustainability}

The fact that most businesses have realized the advantages of their contribution to the environment and are working towards having policies and plans to implement sustainability has become quite evident in present times. 
Many firms have also started implementing green programs to attract the goodwill of customers. It reflects corporates intentions to attract potential customers and build a positive image of the company by conserving natural resources to cash economic opportunities.

Restaurants, Banks, and hotels are part of industries that have become more sensitive to changing customer requirements and have started taking following measures to be eco-friendly:

\section{a) Green Hoteling Initiatives}

Green hoteling is a concept being imbibed by many hotels including Orchid hotel which uses Eco-friendliness as its core competency(D.Rama, Adhikari.A,2011).

Customers are now considering environmental protection as an integral part of doing business. Government regulations are also being brought in regarding environmental safety.

Going green is becoming a norm in the hotel industry in India with consumer awareness on environmental issues and opting for eco-friendly hotels rather than energy guzzlers. The hotel industry is also looking at energy saving and reduced maintenance when energy costs are increasing.

One of the leading chains of hotels in India adopting this is the ITC group of hotels. It's "WelcomEnviron"e initiative to support environment-related causes in the place it operates its hotels is one such effort in that direction. The initiative is based on environment-friendly policies on the principle of recycling, reuse and reduce. The hotel promotes people's awareness of environment-friendly practices, sensitizing employees towards environment and energy conservation and using eco-friendly material and technology (Lakshman and Manjunath, 2015).

ITC Gardenia has been one of the first hotels to have been awarded the US Green Building Council LEED (Leadership in Energy and Environmental Design) Platinum rating, making it one to achieve the highest ratings for green buildings.

A few of the salient features incorporated in these buildings include zero water discharge, reduction in potable water use up to $40 \%$, usage of treated greywater for flushing, use of fly-ash in concrete and bricks, air-conditioning and landscaping, eco-friendly housekeeping practices, high-efficiency equipment, 25-40\% energy saving over conventional buildings.

One of the reasons (Deraman et al.) (2017) why hotels are becoming more and more sensitive towards environmental issues is the increased sensitization of the various stakeholders including shareholders, employees and customers.

Taj group of hotels is also one of the most prestigious hotels known for its heritage throughout. The Taj Group has started its environment-friendly initiative called the EARTH which is an Environment Awareness and Renewal Program. The program EARTH began as a conscious effort to save energy and develop environment-friendly sustainable business strategies and has now been formally adopted across all its properties.

\section{b) Green Banking Initiatives}

Green banking is one such opportunity that can be defined as any form of banking that creates environmental benefits (Narang,2015; Lalon, 2015; Silva, 2015 \& Sindhu, 2015).

According to Lalon (2015), this concept of green banking has been developed by western nations and in the beginning the concept was aimed to minimize the paper usage at banking since cutting trees leads to reduced green forestation, reduces oxygen and increases carbon-dioxide across globe. However, the concept has become an umbrella term which refers to practices and guidelines that makes bank's sustainability in social, economic, and environmental dimensions (Sindhu,2015). Malliga (2016) suggested that green banking is an emerging concept for environment sustainability that promotes environmentally friendly practices for sustainable growth leading to a reduction in the carbon footprint from the banking industry. Many other, studies (Aizawa \& Yang 2010; Kohn 2016; Ciobanu, Negrea \& Andreica 2014; Lalon 2015; Ginovsky 2009 and Singh 2015) highlighted the importance of green banking and how it impacts sustainable growth while considering mostly environmental management for future generations.

Banking industry where the government's push for renewable energy, augurs well for India's green bond market. Indian government's has been working proactively by raising huge sums through green bonds and is committed to go far and beyond to combat climate change(Sheth.R, 2017). Green banking is an effort to reduce internal carbon footprint and external carbon emission.(Vadrale.K,2016).

It is observed that the more hotel and banking industry employees are aware of green initiatives the more responsibly they will behave towards the environment. Increasing their environment awareness fosters and 
creates environment-friendly behaviour amongst employees.

Water harvesting, reduction in water consumption, installation of solar photovoltaic, waste management, green supply chain, paperless business, tree plantation, etc are a few of the initiatives being taken by organizations in India.

Using online banking where customers access accounts through internet (Malliga \& Rewathi 2016; Silva, 2015; Sohail \& Shanmugham,2003; Sudhalaksmi \& Chinnadorai, 2014; Sharma, Sarika \& Gopal, 2012; BOC Annual Report, 2015; Peoples Bank Annual Report, 2015; Lalon, 2015, Narang, 2015; Sindhu, 2015; Rahman and Perves, 2016; Susanto, 2015), payment of utility bills via internet banking, using mobile, banking, SMSes, telephone banking etc. Government, through various awareness programs, policies and regulations are promoting the use of green banking amongst the masses.

The government's sustainable initiatives are playing an important role in enhanced awareness and concern about sustainable development amongst the Millennials but it still has a long way to go to attain sustainable goals:

According to the UNDP report, to ensure healthy living at all ages India will require US\$880 billion till 2020 to achieve around 0.9 of health index. A huge gap of US \$ 305 billion is projected concerning the availability of funds for public health in India.

The Government of India has announced a target of skilling 500 million individuals by 2022. Estimates indicate that only about 2 percent of the existing workforce has undergone formal skill training and about 15 percent of the existing workforce has marketable skills, whereas 90 percent of jobs in India are skill-based and require vocational training (Simon M., 2014). Still, a huge gap needs to be covered.

On the gender gap index which includes equal opportunity and participation, health, and survival, education and empowerment of women also government spending in budgets is low and cautions increase in spending on gender equality.

To ensure the availability and sustainability of water and sanitation for all and cleaning of polluted rivers huge sum needs to be allotted for the purpose to maintain ecological flows of rivers. All of this is expected to be funded by the government.

For inclusive and sustainable economic growth and decent work for all, India will need to enhance its MSME sector which would require growth strategies and generating employment opportunities for youth.

As far as corporates are concerned most leading companies are still not thinking of sustainability as a core business priority. Indian business leaders are focused more on regulatory compliances and not core sustainability. Although there is increasing evidence that embracing sustainability in business leads to long term financial gains, this effect is not yet demonstrated adequately in India. The idea of 'circular economy' where waste becomes a resource is fast catching up but is being followed by large professionally managed companies that also are lagging in financial aspects of business like sharing of profits, paying employees and managing supply chains.

Consumers, in turn, have to put pressure on companies. Consumer awareness of green choices of products and services is still a small urban phenomenon. In most industries, customers don't have access to visible scorecards or certifications for the sustainability of products or services.

Nielsen report 2011, demonstrated that In India still, over 60 percent of people believed there are far more pressing issues than climate change and global warming and the issue would not affect in their lifetime and that technology would take care of it. Regarding the sustainability of the environment also, less than fifty percent of people felt groceries not manufactured by unethical labour practices influence them and only 33 percent were influenced by companies supporting social causes.

Though there is heightened awareness of what goes into the making of a product and that raw materials are not harmful to the environment but ironically there is less concern about companies' social conscience when making a purchasing decision.

Though India is one of the top three countries in Asia pacific that has shown an affinity for eco-friendly products yet the price is an important factor for consumers while making an actual purchasing decision. High price for items like organic food, recycled paper makes it difficult for people to purchase them for everyday use.

\section{Conclusion}

We have attempted to demonstrate how sustainability initiatives by government can lead to a sustained change in the behaviour of Millennials in India.

Adding to the conversation about the incorporation of regulations and policies brought in by the government in 
partnership with industry, we provide a conceptual basis for linking these initiatives to the behaviour of the millennial workforce. Theory of planned behaviour has been used to explain how awareness campaigns by government are leading to changes in attitudes and behaviour of Millennials regarding sustainability.

For this contribution, we have adapted research from Sonigo et al, 2011, D.Rama, Adhikari.A,2011, Narang,2015; Lalon, 2015; Silva, 2015 \& Sindhu, 2015, to suggest that government policies go a long way in enhancing awareness about sustainable development amongst the Millennials thus leading to a change in their behaviour.

It is a known fact that, because of the mammoth size and populace of the country both government and industry together have huge challenges in dealing with the diverse workforce whose expectations change over time. This is leading to impediments in the implementation of policies and programs at ground level. We suggest the integration of sustainable HRM practices and programs with employee value proposition at different stages of life and career.

Further research should investigate the integration of sustainable HRM practices at every level in policies and programs of both the government and the industry for better results. Future research should also focus on examining sustainable practices which have maximum impact on the behaviours of Millennials.

In summary, this article provides an initial conceptualization of how Sustainable initiatives can contribute to behaviour change of Millennials. Although there has been little attempt to bridge Sustainable initiatives research and behaviour implications, additional studies are necessary to empirically test the impact of Sustainable policies and programs on behaviours of Millennials in India.

\section{References}

Abbas, J., Aman, J., Nurunnabi, M., \& Bano, S. (2019). The Impact of Social Media on Learning Behaviour for Sustainable Education: Evidence of Students from Selected Universities in Pakistan. Sustainability, 11, 1683. https://doi.org/10.3390/su11061683

Abbaszadeh, L., Zagreus, L., Lehrer, D., \& Huizenga, C. (2006). Occupant Satisfaction with Indoor Environmental Quality in Green Buildings. Proceedings, Healthy Buildings, 3, 365-370.

Bannister, Watson, \& Wood. (1997). Sustainable cities: transport, energy, and urban form. Environment and Planning and Design, 24, 125-143. https://doi.org/10.1068/b240125

Bhamra, A., Shanker, H., \& Niazi, Z. (2015). Achieving the sustainable development goals in India, A study of financial requirements and gaps. United Nations development program, Ministry of Environment, forest and climate change, Government of India.

Biddappa, K. T. (2011). Nielsen, Indian consumers conscious of the environmental benefits of sustainable practices.

Chaudhary, R., \& Bisai, S. (2018). Factors influencing the green purchase behaviour of millennials in India. Management of Environmental Quality, 29(5), 798-812. https://doi.org/10.1108/MEQ-02-2018-0023

Dabija, D., Bejan, M., \& Grant, B. (2018). The impact of consumer green behaviour on green loyalty among retail formats: A Romanian case study. Moravian geographical reports, 26(3), 173-185. Retrieved from http://www.geonika.cz/mgr.html

Fuller, J. (2013). Rationality and the generalization of randomized controlled trial evidence. International journal of public health policy and health services research, 19(4), 644-647. https://doi.org/10.1111/jep.12021

Jain, H. (2017). What the millennial Indian wants: not cars \& houses, just fun \& convenience. economic times contributors.

Martin, J. (2015). The economy: a pathway to sustainability or a nightmarish form of neoliberal capitalism? ecological economics, 121, 149-159. https://doi.org/10.1016/j.ecolecon.2015.11.027

McMichael. (2013). Globalization, climate change, and human health - NCBI. N Engl J Med, 368(14), 1335-43. https://doi.org/10.1056/NEJMra1109341

Muralidharan, S., \& Xue, F. (2016). Personal networks as a precursor to a green future: A study of "green" consumer socialization among young millennials from India and China. Young consumers, 17(3), 226-242. https://doi.org/10.1108/YC-03-2016-00586

Muralidharan, S., Rej, F., \& Xue, F. (2015). Understanding the Green Buying Behaviour of Younger Millennials from India and the United States: A Structural Equation Modelling Approach. Journal of International 
Consumer. Retrieved November 10, 2019, from http://www.tandfonline.com/loi/wicm20

Nollman, M. R. (2013). Sustainability initiatives in the workplace and employee productivity. Retrieved from http://opensiuc.lib.siu.edu/gs_rp/441

Purvis, B., Mao, Y., \& Robinson, D. (2019). Three pillars of sustainability-In search of conceptual origins. Sustainability Science, 14, 681-695. https://doi.org/10.1007/s11625-018-0627-5

Rama, D., \& Adhikari, A. (2011). orchid ecotel-leveraging green hoteling as a core competency, Ivey publishing.

Schoolman, D., Shriberg, M., Schwimmer, S., \& Tysman, M. (2014). Green cities and ivory towers: how do higher education sustainability initiatives shape millennials' consumption practices? J Environ Stud Sci. https://doi.org/10.1007/s13412-014-0190-z

Sharma, R. (2019). Indian millennials' optimism stands out amidst global counterparts' disillusionment.

Singhal, S., Deepak, A., \& Marwaha, V. (2018). Green initiatives practices in Indian hotels. IOSR Journal of Business and Management (IOSR-JBM), 20(8), 10-13. Retrieved from www.iosrjournals.org

Vadrale, K. (2016). Green banking initiatives by Indian private and public sector banks, Conference: Green Banking for Green Industry and Green Economy At: Belgavi.

Verma, K. (2012). Hotels in India going green.

Xun, W., Khan, A., \& Michael, E. (2010). climate change epidemiology: methodological challenges. Int $j$ public health, 55, 85-96. https://doi.org/10.1007/s00038-009-0091-1

Zargar, H. (2018). Young generation distrustful of businesses, as loyalty and confidence dip. livemint.

\section{Copyrights}

Copyright for this article is retained by the author(s), with first publication rights granted to the journal.

This is an open-access article distributed under the terms and conditions of the Creative Commons Attribution license (http://creativecommons.org/licenses/by/4.0/). 